\title{
How Much Does Local Job Growth Improve Employment Outcomes of the Rural Working Poor?
}

\author{
Elizabeth E. Davis and Bruce A. Weber*
}

\begin{abstract}
Using administrative data from Oregon, the study analyzes the impact of local labor market conditions on the employment and earnings of low-income adults. The study finds that local job growth helps the working poor, resulting in higher earnings, more frequent employment, and more quarters with earnings above the poverty level. However, the evidence suggests that the effect of local job growth on employment outcomes may be weaker in rural areas than in urban areas. This finding raises concerns about the ability of low-income adults (including former welfare recipients) to achieve economic self-sufficiency in rural areas.
\end{abstract}

\section{INTRODUCTION}

There is increasing emphasis at both the state and federal level on the need to increase the employment and earnings of low-income families, including current and potential welfare recipients. Yet, there is relatively little information available about the dynamics of wage progression and job stability among lowincome workers. The success of welfare reform depends not only on whether welfare recipients can move off the caseload (or avoid participating in the first place), but also whether they can find and keep jobs and over time increase their earnings sufficiently to move their families out of poverty. In rural areas, this transition is likely to be even more difficult, given the challenges facing some rural areas in terms of unemployment, inadequate earnings, and job instability.

An implicit assumption behind much of the current emphasis on welfareto-work is that getting a job, any job, will lead to long-term success (defined as economic self-sufficiency) for low-income families. Studies tracking former welfare recipients generally find that many become employed but often have low earnings and high levels of job turnover. The Post-Employment Services Demonstration found that 30 to 40 percent of former welfare recipients were unemployed a year after finding their initial job, and many were in jobs with little potential for wage growth (Rangarajan 1996). Other studies, such as Pavetti (1997), Pavetti and Acs (1995), and Parrott (1998), also find high levels of turnover in employment among former welfare recipients.

\footnotetext{
*Assistant Professor, Department of Applied Economics, University of Minnesota, St. Paul; and Professor, Department of Agricultural and Resource Economics, Oregon State University, Corvallis. The research reported in this paper was supported by the U.S. Department of Agriculture National Research Initiative Competitive Grants Program Award No. 97-35401 and by Project 814 of the Oregon Agricultural Experiment Station. The authors appreciate the assistance of the Oregon Employment Department in accessing the data from the Oregon Shared Information System, and gratefully acknowledge the excellent research assistance of Sue Wang. We also benefited from the perceptive comments of three anonymous reviewers.
} 
The focus of most of these studies has been on those receiving or leaving public assistance (Aid to Families with Dependent Children and its successor, Temporary Assistance to Needy Families), and on individual (or supply-side) factors affecting job retention, including the person's education or skill level, child care access, and ability to conform to workplace rules. Less attention has been paid to the impacts of overall labor market conditions on the dynamics of employment stability for low-income workers. Demand-side variables are often not included due to data limitations or lack of specific information about the location of the individual, or included only at the state or Census region level.

This paper uses a unique linked administrative database from Oregon to analyze the impact of local labor market demand conditions on the employment and earnings of working low-income adults. The availability of this unique data set allows us to link employment data for individuals with county-level data on economic conditions. We then can investigate the potential for a differential impact of local labor market conditions in rural versus urban areas. The impact of "welfare reform" may vary across localities in part because of differences in local labor market opportunities.

This paper also extends recent research by including a broad group of working poor adults, not only current or former welfare recipients. As welfare caseloads have fallen dramatically, the characteristics of welfare recipients, and their success in the labor market, are likely to have changed. The study includes a broader group of working poor adults in order to analyze the outcomes for the low-income job market as a whole.

\section{SUMMARY OF RECENT RELATED RESEARCH}

A number of recent studies have analyzed the impact of local labor demand on welfare recipiency and earnings of current and former welfare recipients. ${ }^{1}$ Hoynes (2000), Harris (1996), and Fitzgerald (1995) each look at the impact of local labor market conditions on welfare receipt. While the latter two found small or insignificant effects, Hoynes (2000), using a large longitudinal data set from California, determined that local labor market conditions do affect welfare receipt. She found that higher unemployment rates and lower employment growth in an area significantly increased the length of welfare spells and raised the probability of returns to welfare.

Bound and Holzer (1996) look more broadly at the less-skilled labor market and conclude that drops in labor demand negatively impact younger, lesseducated, and minority workers to a greater extent than they do more mobile and more skilled workers. Bartik (1996) also has analyzed how individual earnings, work hours, wages, and poverty status change in response to changes in local labor demand and industrial mix in metropolitan areas. These studies generally look at metropolitan statistical areas, however, or in some cases counties, and do

\footnotetext{
${ }^{1}$ A growing number of studies have looked at the impact of economic conditions on welfare caseloads at the state level, rather than focusing on the impacts on individual outcomes. See, for example, Bartik and Eberts (1999), Blank (1997), U.S. Council of Economic Advisors (1997), and Ziliak et al. (2000).
} 
Rural Working Poor?

not focus specifically on the challenges faced by rural residents in more widely dispersed labor markets.

Studies of the low-income population have highlighted differences in labor force behavior between residents in metro and nonmetro areas (e.g., Deavers and Hoppe 1992), and suggest that barriers to finding and keeping employment may be greater in rural labor markets. In nonmetro areas, poor families are more likely to be working and more likely to be underemployed (working part time, earning low wages, or unemployed), compared to poor families in metro areas (Findeis and Jensen 1998). Working single mothers with children have higher rates of poverty in rural areas than in urban areas, with over one-third of them in poverty in rural areas (Lichter and Jensen 2002). Differences in earnings across rural and urban areas may reflect both differences in the characteristics of residents and differences in local labor market conditions.

Several studies examine the impact of economic conditions on poverty and earnings in rural areas. Many of these studies find that industrial base, sectoral changes, and class stratification affect poverty rates or average earnings in rural counties (Gorham 1992; Brown and Hirschl 1995; Duncan 1996; Tickamyer 1992). One study (Findeis et al. 1992) looks in detail at transitions out of poverty of families who have ever lived in nonmetropolitan counties. Using national survey data, they find that the main strategy for exiting poverty for female-headed households is to work more hours. Mills (2000) finds that both local economic conditions and individual characteristics explain differences in the likelihood of finding a job in metro versus nonmetro areas. These studies underscore the importance of local labor market conditions in affecting poverty in rural areas.

Studies of the impact of local labor market conditions on employment use a variety of measures of labor demand. Most use a measure of employment growth, either total growth or for particular sectors. Bartik (1991) and Bound and Holzer (1996), for example, include predicted employment growth, using national changes in employment growth by sector with the area's mix of sectors to predict an area's growth. These studies generally find a positive association between total employment growth and individual labor market outcomes. Other studies use unemployment rates as the measure of labor market conditions. For example, Cain and Finnie (1990) and Freeman and Rodgers (1999) estimate that lower unemployment rates lead to higher employment rates and earnings for young African American men. Thus, there is a growing empirical literature estimating the links between overall labor market conditions and outcomes for low-income individuals.

\section{EMPIRICAL MODEL AND DATA}

This study uses linked administrative data files from Oregon to analyze the employment transitions and earnings outcomes of working poor adults. The study population is adults aged 18 to 64 who qualified for the Oregon Health Plan $(\mathrm{OHP})$ in 1994 and who were working during the calendar quarter in which they 
enrolled in the OHP. ${ }^{2}$ To qualify (in 1994), a family's income needed to be below the relevant federal poverty threshold for at least one month. The database links individual program participation data with quarterly earnings from 1994 to 1996 collected from employers by the Oregon Employment Department. ${ }^{3}$

The study sample of working poor Oregonians consists of the 60,160 adults who were employed at the time of enrollment in the OHP in 1994. ${ }^{4}$ Most were female ( 60 percent), under age 30 (44 percent), and white ( 82 percent), as shown in Table 1. Less than 3 percent had a disability known to the state agency, though for many this information is not reported. Most have a high school degree. ${ }^{5}$

\section{TABLE 1}

Comparison of Demographic Characteristics of Study Sample and Oregon Working Poor Population

\begin{tabular}{|c|c|c|}
\hline & $\begin{array}{c}\text { Study Sample }(\mathrm{N}=60,160) \\
\text { Percentage }\end{array}$ & $\begin{array}{c}\text { Comparison Sample }(\mathrm{N}=270) \\
\text { Percentage }\end{array}$ \\
\hline \multicolumn{3}{|l|}{ AGE } \\
\hline Under 30 & 43.9 & 44.2 \\
\hline $30-39$ & 33.6 & 29.0 \\
\hline 40 and older & 22.6 & 26.8 \\
\hline \multicolumn{3}{|l|}{ GENDER } \\
\hline Female & 59.5 & 45.7 \\
\hline Male & 40.5 & 54.3 \\
\hline \multicolumn{3}{|l|}{ ETHNICITY } \\
\hline African American & 2.9 & 2.2 \\
\hline Asian & 2.5 & 3.0 \\
\hline Hispanic & 9.5 & 11.5 \\
\hline Native American & 1.4 & 0.7 \\
\hline Caucasian & 81.6 & 78.8 \\
\hline Other/missing & 2.0 & 3.7 \\
\hline \multicolumn{3}{|l|}{ EDUCATION LEVEL } \\
\hline Less than high school degree & 13.7 & 13.0 \\
\hline High school degree & 30.5 & 32.6 \\
\hline More than high school degree & 12.0 & 50.4 \\
\hline Missing/unknown & 43.8 & 4.1 \\
\hline
\end{tabular}

Sources: Study sample of working Oregon Health Plan participants (age 18 to 64) from the Oregon Shared Information System. Comparison sample of Oregon population of working poor (age 18 to 64) from authors' calculations based on the respondent file of the1994 Oregon Population Survey.

The working age (18-64) OHP participants who were employed at the time of enrollment (the study sample) appear to represent the Oregon working poor adult population aged 18-64 in 1994 quite well. When compared with the working poor subsample of the 1994 Oregon Population Survey, working 1994 OHP participants aged 18-64 have similar age, ethnicity and education characteristics (see ${ }^{2}$ The OHP included an expansion of the federal Medicaid program to cover working poor families and was allowed under special waivers from the federal government.

${ }^{3}$ Earnings data are collected from employers covered by the Unemployment Insurance system and so will exclude information from a small number of employers who are not covered, and from the self-employed. The Oregon Employment Department estimates that covered employment represents 91 percent of all employment in 1996.

"We use the term "working poor" for convenience. In some cases, the family may have had annual income above the federal poverty threshold for 1994 even though they qualified for the OHP based on one month's income.

5 Information on education level is missing for about 40 percent of the sample so the estimations include a dummy for missing education in the control variables. In most cases, the missing education dummy has a significant negative effect on employment and earnings. It may be, therefore, a proxy for unobserved variables that affect employment outcomes. 

Rural Working Poor?

Table 1). With respect to gender, however, females are over represented in the working OHP population relative to the working poor in Oregon. The effect of this difference is controlled for in the empirical model, as discussed below.

The primary objective of this study is to investigate the relationship between local labor market conditions and employment and earnings outcomes for the working poor. The local labor market facing the individual is defined based on commuting zones (Tolbert and Sizer 1996). There are 18 commuting zones in Oregon, several of which cross state boundaries, and which vary in size from one major metropolitan area to 12 nonmetropolitan zones with either a small town or small urban center. By using commuting zones, we are attempting to capture more accurately the set of labor market opportunities available to the individual. Counties may be too small to represent an economic unit in some places, and states are probably too large. Commuting zones as designated by Tolbert and Sizer (1996) are based on actual commuting data and so reflect more realistic labor markets by including multiple counties and crossing state boundaries.

TABLE 2

Economic Conditions of Oregon's Commuting Zones

\begin{tabular}{lcc}
\hline Type of Commuting Zone & $\begin{array}{c}\text { Unemployment } \\
\text { Rate, } 1994\end{array}$ & $\begin{array}{c}\text { Percent Change } \\
\text { in Employment } \\
1994-96\end{array}$ \\
\hline METROPOLITAN & & \\
Major metro (Portland) & 4.4 & 8.5 \\
Medium metro (Eugene) & 5.2 & 7.1 \\
Small metro & 6.8 & 2.6 \\
Medford & 7.3 & 5.3 \\
Richland & 6.3 & -0.1 \\
NONMETROPOLITAN & & \\
Large urban center & 8.2 & 6.6 \\
Bend & 7.2 & 7.2 \\
Longview & 9.3 & 3.5 \\
Small urban center & 8.1 & 5.1 \\
Klamath Falls & 10.9 & 6.2 \\
LaGrande & 6.9 & 2.5 \\
Newport & 5.7 & 6.5 \\
Ontario & 7.6 & 5.9 \\
Roseburg & 8.9 & 5.0 \\
The Dalles & 8.6 & 4.5 \\
Small town & 8.9 & 4.5 \\
Brookings & 10.0 & 0.9 \\
Burns & 10.1 & 12.1 \\
Condon & 6.0 & 1.4 \\
Enterprise & 9.4 & 1.4 \\
John Day & 9.5 & 0.5 \\
Lakeview & 8.4 & \\
\hline Not The & &
\end{tabular}

Note: The type of commuting zone is determined by the size of the largest population center (Tolbert and Sizer 1996). 
As shown in Table 2, economic conditions varied widely across the commuting zones of Oregon during this time period. Generally, economic conditions are less favorable in rural labor markets as compared to urban labor markets. ${ }^{6}$ Employment growth (percentage change in total employment over the 1994-96 period) is generally higher in metro labor markets than nonmetro labor markets. In addition, the average unemployment rate increases almost monotonically as the size of a labor market's urban center decreases. Nonetheless, within each type of commuting zone there is also considerable variation in economic conditions. Not all rural areas perform worse than urban parts of the state. For example, job growth between 1994 and 1996 in the small town commuting zones near Condon and Brookings exceeded job growth in the small metropolitan zone of Richland.

This study follows an approach similar to studies such as Bartik (1991), Bound and Holzer (1996), and Freeman and Rodgers (1999) in order to determine the relative impact of human capital and demographic characteristics versus local labor market conditions in determining employment outcomes for low-income workers. The basic empirical model takes the form:

$$
Y_{i}=\beta^{\prime} X_{i}+\gamma^{\prime} L M_{i}+e_{i},
$$

where $Y_{i}=$ the labor market outcome for individual $I, X_{i}=$ a vector of human capital and sociodemographic variables, $\mathrm{LM}_{\mathrm{i}}=$ measures of local labor market conditions in the commuting zone, $\beta$ and $\gamma$ are parameters to be estimated, and $e_{i}$ is an error term with properties that depend on the model specification (as described below).

This study investigates the impact of local labor market conditions on three employment-related outcomes for this group of working poor adults: 1) average earnings in the second year after intake (quarters 5-8 after the intake quarter); 2) number of quarters worked during the first eight quarters after intake; and 3) number of quarters with earnings above the poverty threshold for a family of three. The poverty threshold for a family of three is used as a yardstick to measure "above-poverty" earnings. " The earnings equation is estimated using the "Tobit" model to account for the occurrence of zero earnings. The number of quarters worked and the number of quarters with above-poverty earnings are estimated using ordered probit models. ${ }^{8}$ While ordered probit models are commonly used for analysis of multinomial choice variables, they are also appropriate for discrete data. In this case, the ordering matters (unlike a multinomial logit model, for

6 In this paper, rural (urban) is used interchangeably with nonmetropolitan (metropolitan). The commuting zones are classified as metropolitan or nonmetropolitan based on whether the commuting zone has a metropolitan county: if the zone has a metropolitan county, it is classified as metropolitan (urban). Some of the metropolitan commuting zones include nonmetropolitan counties within their boundaries. Nonmetropolitan (rural) commuting zones do not include any metropolitan counties.

7The administrative data only include information on the earnings of the individual; therefore, it is unknown whether the family income is above the poverty line because, for example, other members of the family may have earnings. This measure is a convenient way to assess movement toward economic self-sufficiency.

${ }^{8}$ An alternative approach would be to estimate Poisson or negative binomial models, which are commonly used with count data. In this case, however, the ordered probit specification is more appropriate because the data reflect an underlying continuous process, that is, employment (Cameron and Trivedi 1998). For comparison purposes, zero-inflated negative binomial models were also estimated and produced results similar to those reported here. 
example), because the probability of being employed four quarters is not independent of the probability of being employed three quarters.

The economic condition of the local labor market is measured by the percentage change in total employment between 1994 and 1996. A key purpose of our study is to test whether the impact of job growth differs in rural and urban parts of the state. An interaction term between a rural dummy variable (which equals one if the person resides in a nonmetropolitan commuting zone) and job growth is included in order to test for a differential impact of labor market conditions in rural versus urban areas.

Control variables in each model are fairly standard for wage and employment equations and include the individual's race, gender, education level, age and age squared, and a disability indicator. ${ }^{9}$ Unfortunately, the database does not include information on marital status or number of children, two factors that may strongly influence employment decisions and outcomes. In order to test whether these missing demographic variables impact the results, community-level variables were included as regressors in each of the models (see Hoynes 2000 for a similar approach). Two variables, the percent married and the percent with children under age 16, were calculated for each of the commuting zones based on the 1994 Oregon Population Survey. Findings from the models that include the countylevel demographic variables (available from the authors) suggest that exclusion of the characteristics is not impacting the estimates of the effects of job growth. Both of the county-level demographic variables are usually not statistically significant and the estimated coefficient on job growth remains relatively unchanged. As an additional test, separate equations for men and women were estimated to try to determine whether the exclusion of certain demographic characteristics was affecting the results. Typically, factors such as the number of children or marital status affect women's labor market outcomes more than men's. The similarity of the estimated coefficients on job growth in the separate equations (described later in the text) suggests that the lack of a full set of demographic characteristics is not substantially biasing the results.

Note that the data set identifies the residence of the person at intake, and does not track the person's changes in residence. However, movement of the poor between commuting zones was not extensive during the mid-1990s in Oregon. According to the 1996 Oregon Population Survey, in the previous five years about 10 percent of poor Oregonians had moved between commuting zones, and 19 percent had moved in from another state or country. Since 1991-96 was a period of net in-migration at a rate of about 1 percent per year, one can reasonably infer that outmigration would be less than 19 percent, perhaps around 14 percent. Since our data are for a two-year period, the migration rates between commuting zones would likely be less than half the five-year rates reported in the survey: perhaps 2 percent of poor households moved between commuting zones during 1994-96, and 7 percent moved out of state. Thus, movement between commuting zones

\footnotetext{
9Sample means for all variables are included in an appendix table.
} 
and out-of-state migration are unlikely to have important effects on the conclusions regarding rural and urban labor markets.

\section{FINDINGS: EMPLOYMENT AND EARNINGS}

A number of studies have demonstrated that difficulties with job retention and low earnings are common among former welfare recipients (see, for example, Rangarajan 1996, Pavetti 1997, Pavetti and Acs 1995, and Parrott 1998). The situation appears similar for these working poor adults in Oregon, despite the fact that they already were working (and may not have been on welfare) when they enrolled in the OHP. Looking at the first eight quarters after the person enrolled in the OHP, many of these working poor adults do work steadily (see Table 3 ). ${ }^{10}$ About 40 percent report earnings in each of the eight quarters. Another 20 percent work six or seven out of eight quarters. But for the remaining 36 percent whose employment is limited or intermittent, total earnings are clearly constrained by periods of nonemployment. About 14 percent worked two or fewer quarters, despite having been employed when first enrolled in the OHP. Full-year work, year after year, appears to be elusive for many of these working poor adults.

TABLE 3

Employment Outcomes of the Working Poor in Oregon (Adults on the Oregon Health Plan Employed at Intake, 1994)

\begin{tabular}{|c|c|c|c|c|}
\hline \multirow[b]{2}{*}{ \# of quarters } & \multicolumn{2}{|c|}{ \# of quarters worked since intake } & \multicolumn{2}{|c|}{ \# of quarters with earnings $>\$ 3,160^{2}$} \\
\hline & $\begin{array}{c}\text { Percent } \\
\text { in urban areas } \\
(\mathrm{N}=46,834)\end{array}$ & $\begin{array}{c}\text { Percent } \\
\text { in rural areas } \\
(\mathrm{N}=13,326)\end{array}$ & $\begin{array}{c}\text { Percent } \\
\text { in urban areas } \\
(\mathrm{N}=46,834)\end{array}$ & $\begin{array}{c}\text { Percent } \\
\text { in rural areas } \\
(\mathrm{N}=13,326)\end{array}$ \\
\hline 0 & 0.5 & 0.6 & 46.2 & 53.4 \\
\hline 1 & 6.5 & 7.5 & 10.7 & 11.6 \\
\hline 2 & 6.5 & 7.2 & 8.1 & 7.2 \\
\hline 3 & 6.5 & 7.2 & 6.2 & 5.7 \\
\hline 4 & 7.4 & 7.6 & 5.7 & 4.9 \\
\hline 5 & 8.1 & 8.1 & 5.1 & 4.4 \\
\hline 6 & 9.7 & 10.6 & 4.9 & 4.1 \\
\hline 7 & 12.7 & 12.9 & 5.0 & 3.5 \\
\hline 8 & 42.2 & 38.5 & 8.0 & 5.2 \\
\hline Total $^{b}$ & 100 & 100 & 100 & 100 \\
\hline Mean \# of quarters & 5.9 & 5.8 & 2.2 & 1.8 \\
\hline
\end{tabular}

${ }^{\mathrm{a}}$ The annual poverty threshold for a family of three with two children $(\$ 12,641$ in 1996 , or $\$ 3,160$ per quarter) is used as a convenient measure of "above-poverty earnings."

botals may not sum to 100 due to rounding.

Table 3 also illustrates that while many of these adults were working more or less steadily, few consistently had "above-poverty" earnings. The poverty threshold for a family of three is used as an approximate measure of "abovepoverty" earnings (the annual poverty threshold for a family of three with two children was $\$ 12,641$ in 1996 , or $\$ 3,160$ per quarter). A majority of these workers rarely experience quarters in which their earnings are above that threshold. As shown in Table 3, about half of the group never had earnings above the poverty 10Note that all individuals were tracked for eight quarters after enrolling in the OHP in 1994, regardless of the quarter in which they enrolled in 1994. The data do not identify continuously employed respondents. 
Rural Working Poor?

threshold. In rural areas, 53 percent had no quarters with above-poverty earnings compared to 46 percent in urban areas. At the other extreme, 23 percent in urban areas had above-poverty earnings in five or more quarters, as did 17 percent in the rural areas. ${ }^{11}$

Despite relatively consistent employment for many of these working poor adults in Oregon, most have low earnings. Earnings during the intake quarter (the quarter in which the person enrolled in the OHP) averaged only $\$ 1,784$. However, average earnings did increase considerably over time. As shown in Table 4, quarterly earnings in the second year after intake averaged $\$ 2,087$, an increase of 17 percent. This average is calculated for all individuals (even those no longer working) and all quarters (including quarters in which an individual's reported earnings were zero), thus capturing the average earnings experience for the entire sample. ${ }^{12}$ Note that average earnings were higher for those in the urban areas compared with rural areas, and increased faster. The urban-rural gap in quarterly earnings increased from 5 percent at intake to 15 percent in the second year after intake (from $\$ 84$ to $\$ 284$ ).

TABLE 4

Average Earnings of the Working Poor in Oregon (Adults on the Oregon Health Plan Employed at Intake, 1994)

\begin{tabular}{lcccc}
\hline & $\begin{array}{c}\text { All } \\
(\mathrm{N}=60,160)\end{array}$ & $\begin{array}{c}\text { Urban } \\
(\mathrm{N}=46,834)\end{array}$ & $\begin{array}{c}\text { Rural } \\
(\mathrm{N}=13,326)\end{array}$ & $\begin{array}{c}\text { Rural-Urban } \\
\text { Difference }\end{array}$ \\
\hline Earnings during intake quarter (in 1994) & $\$ 1,784$ & $\$ 1,803$ & $\$ 1,719$ & $\$ 84$
\end{tabular}

Average quarterly earnings for all quarters (including quarters with zero earnings) in second year after intake

$\$ 2,087 \quad \$ 2,150 \quad \$ 1,865$

$\$ 284$

Average quarterly earnings in quarters worked during second year after intake

$\$ 2,746 \quad \$ 2,810 \quad \$ 2,519$

$\$ 290$

Average annual earnings for all four quarters (including quarters with zero earnings) in second year after intake $\$ 8,348 \quad \$ 8,600 \quad \$ 7,463$ $\$ 1,137$

Note: Earnings are in nominal dollars.

While average quarterly earnings increased over the follow-up period, annual earnings remained quite low for most of these workers. Mean total earnings in the second year of follow-up averaged $\$ 8,348$. Average annual earnings are calculated for all individuals in the sample and all quarters (including quarters in which an individual's reported earnings were zero). Annual earnings are low for these adults both because quarterly earnings are low and because of periods of nonemployment. Only about half of the sample had earnings in all four quarters during the second year after intake and 18 percent of the sample had zero reported earnings for all four quarters. Earnings are about 15 percent higher for those in urban areas compared to their counterparts in rural areas.

\footnotetext{
${ }^{11}$ Note that these individuals may no longer qualify for the OHP.

12.There were no reported earnings for about one-third of the workers in each quarter of the second year after intake. If the quarters in which there are no reported earnings are excluded, average quarterly earnings during the quarters worked increased by more than 50 percent, to $\$ 2,746$.
} 
To better illustrate changes in earnings over the follow-up period, Table 5 provides a transition matrix that shows earnings in the eighth quarter after intake compared to earnings at intake. For those earning less than $\$ 1,000$ in their intake quarter, about 17 percent earned something, but still less than $\$ 1,000$, eight quarters later. Almost 44 percent increased their earnings: about 25 percent earned between $\$ 1,000$ and $\$ 3,000$ and nearly 20 percent earned more than $\$ 3,000$. Almost 40 percent, however, had no reported earnings in the eighth quarter after intake. In sum, among those with the lowest earnings at intake, over 40 percent had increased their quarterly earnings two years after intake and about 40 percent had no reported earnings.

\section{TABLE 5}

Transition Matrix: Percentage of Workers in Each Earnings Range at Intake and in 8th Quarter after Intake

\begin{tabular}{lcccc}
\hline $\begin{array}{l}\text { Earnings during 8th quarter } \\
\text { after intake }\end{array}$ & $\begin{array}{c}<\$ 1,000 \\
(\mathrm{~N}=21,678)\end{array}$ & $\begin{array}{c}\$ 1,000 \text { to } \$ 3,000 \\
(\mathrm{~N}=27,905)\end{array}$ & $\begin{array}{c}\$ 3,000 \text { to } \$ 5,000 \\
(\mathrm{~N}=8,656)\end{array}$ & $\begin{array}{c}>\$ 5,000 \\
(\mathrm{~N}=1,921)\end{array}$ \\
\hline No earnings in 8th quarter ${ }^{\mathrm{a}}$ & $39.1 \%$ & $29.8 \%$ & $21.3 \%$ & $19.8 \%$ \\
Less than $\$ 1,000$ & 17.3 & 10.3 & 5.2 & 3.2 \\
$\$ 1,000$ to $\$ 3,000$ & 24.0 & 28.9 & 14.1 & 7.0 \\
$\$ 3,000$ to $\$ 5,000$ & 13.9 & 22.2 & 34.1 & 13.6 \\
$\$ 5,000$ or more & 5.7 & 8.8 & 25.4 & 56.4 \\
Total & $100 \%$ & $100 \%$ & $100 \%$ & $100 \%$
\end{tabular}

${ }^{a}$ The percentage with no earnings in the 8th quarter may be slightly overstated because some workers may have moved out of state or have become self-employed. Totals may not sum to 100 due to rounding.

Most of those earning more than $\$ 1,000$ in the intake quarter were able to maintain or increase their earnings in the eighth quarter after intake. For those earning $\$ 1,000-\$ 3,000$ and $\$ 3,000-\$ 5,000$ at intake, 60 percent maintained or increased quarterly earnings two years later. For those earning over $\$ 5,000$ at intake, 56 percent continued to earn over $\$ 5,000$ eight quarters later. Overall, the transition matrix shows a fairly wide variation in earnings changes: most of the working 1994 enrollees in the OHP showed increased earnings after eight quarters, but a significant minority (about 40 percent) had decreased or no reported earnings.

In sum, the working poor adults in rural areas worked slightly fewer (0.14) quarters in the follow-up period (about two weeks less on average), earned almost $\$ 300$ less per quarter, and experienced fewer quarters with above-poverty earnings than their urban counterparts. Are these outcomes worse in rural areas because of differences in local labor market conditions, or due to some other factor that differs between rural and urban areas?

\section{FINDINGS: THE IMPACT OF LOCAL LABOR MARKET CONDITIONS}

To test whether job growth has a differential effect in urban and rural areas, the model includes both job growth and an interaction term between job growth and the rural indicator in the model. The estimated coefficient on job 


\section{Rural Working Poor?}

growth therefore measures the impact in urban areas, and the impact in rural areas is found by summing the job growth coefficient and the coefficient on the interaction term. Note that in all models robust standard errors are estimated, taking into account the fact that errors within each commuting zone may be correlated. If the estimated standard errors are not corrected for this correlation, they are likely to be too small. ${ }^{13}$

TABLE 6

Estimation Results: Number of Quarters with Earnings

\begin{tabular}{|c|c|c|}
\hline Variable & $\begin{array}{l}\text { Estimated } \\
\text { OLS } \\
\text { Coefficient }\end{array}$ & $\begin{array}{c}\text { Estimated } \\
\text { Ordered Probit } \\
\text { Coefficient }\end{array}$ \\
\hline Constant & $\begin{array}{l}4.3768^{* *} \\
(0.2142)\end{array}$ & - \\
\hline Less than high school degree & $\begin{array}{l}-0.4335^{* *} \\
(0.0421)\end{array}$ & $\begin{array}{l}-0.1997^{* *} \\
(0.0178)\end{array}$ \\
\hline High school degree & $\begin{array}{c}-0.1145^{*} \\
(0.0474)\end{array}$ & $\begin{array}{l}-0.0538^{* *} \\
(0.0175)\end{array}$ \\
\hline Missing education info & $\begin{array}{l}-0.1173^{* *} \\
(0.0260)\end{array}$ & $\begin{array}{l}-0.0179 \\
(0.0147)\end{array}$ \\
\hline African American & $\begin{array}{l}-0.1493^{* *} \\
(0.0235)\end{array}$ & $\begin{array}{l}-0.0634^{* *} \\
(0.0107)\end{array}$ \\
\hline Hispanic & $\begin{array}{l}0.5080^{* *} \\
(0.1172)\end{array}$ & $\begin{array}{c}0.2272^{* *} \\
(0.0609)\end{array}$ \\
\hline Asian & $\begin{array}{c}0.3713^{* *} \\
(0.0580)\end{array}$ & $\begin{array}{c}0.1919^{* *} \\
(0.0401)\end{array}$ \\
\hline Native American & $\begin{array}{l}-0.2768^{* *} \\
(0.0757)\end{array}$ & $\begin{array}{l}-0.1225^{* *} \\
(0.0330)\end{array}$ \\
\hline Other race/ethnicity & $\begin{array}{l}0.1202^{* *} \\
(0.0322)\end{array}$ & $\begin{array}{l}0.0355^{* *} \\
(0.0110)\end{array}$ \\
\hline Male & $\begin{array}{l}0.1737^{* *} \\
(0.0575)\end{array}$ & $\begin{array}{c}0.0746^{* *} \\
(0.0244)\end{array}$ \\
\hline Disabled & $\begin{array}{l}-0.3935^{* *} \\
(0.0271)\end{array}$ & $\begin{array}{l}-0.1790^{* *} \\
(0.0132)\end{array}$ \\
\hline Age & $\begin{array}{l}0.0695^{* *} \\
(0.0115)\end{array}$ & $\begin{array}{l}0.0343^{* *} \\
(0.0048)\end{array}$ \\
\hline Age squared & $\begin{array}{l}-0.00082^{* *} \\
(0.00015)\end{array}$ & $\begin{array}{l}-0.00040^{* *} \\
(0.00006)\end{array}$ \\
\hline Job growth & $\begin{array}{l}0.0375^{* *} \\
(0.0123)\end{array}$ & $\begin{array}{c}0.0166^{* *} \\
(0.0053)\end{array}$ \\
\hline RURAL*Job growth & $\begin{array}{l}-0.0186 \\
(0.0156)\end{array}$ & $\begin{array}{l}-0.0090 \\
(0.0074)\end{array}$ \\
\hline
\end{tabular}

* Significant at the $1 \%$ level. "Significant at the 5\% level. +Significant at the $10 \%$ level. Estimated robust standard errors in parentheses.

The omitted categories are female, white, and having more than a high school education.

Table 6 shows the results for the ordered probit model for number of quarters with earnings, along with OLS coefficients for comparison purposes. The demographic variables significantly affect the probability of more quarters worked in predicted ways: the estimated ordered probit coefficients are highly significant for age, disability status, gender, and education. Job growth is also significant and positive, suggesting that more job growth is associated with a greater likelihood of more quarters of work. The rural-job growth interaction term

${ }^{13}$ Stata Statistical Software calculates the Huber-White or sandwich robust estimators with a "cluster" option that relaxes the assumption of independence within clusters (StataCorp 2001b). 
is negative and not significant at the $5 \%$ level. The negative coefficient suggests that the impact of job growth in rural areas would be less than half the size in urban areas, but given the lack of statistical significance, the evidence is weak. However, the estimated impact of job growth in rural areas is also not statistically significantly different from zero, based on testing the null hypothesis that the sum of the coefficients on job growth and on the rural-job growth interaction term equals zero. ${ }^{14}$ In other words, because the rural effect is not estimated very precisely, the confidence intervals overlap so we cannot reject either that it is significantly different from zero or that it is significantly different from the effect in urban areas. These results together suggest, however, that the impact of job growth on employment is smaller in rural areas than in the urban areas.

The ordered probit coefficients themselves are not interpretable in a straightforward way because the model is nonlinear (Greene 1997). The marginal impact of each of the explanatory variables on the probability of each outcome $\left(0,1,2, \ldots, 8\right.$ quarters with earnings) can be computed. ${ }^{15}$ Table 7 provides estimated marginal effects for three outcomes: no quarters with earnings, four quarters with earnings, and eight quarters with earnings. For example, a 1 percent increase in job growth between 1994 and 1996 is associated with an increase of 0.0065 in the probability of having eight quarters with earnings. At the same time, more job growth is associated with a lower probability of having zero quarters with earnings. In other words, more job growth would shift the distribution rightward, so more people would have more quarters with earnings and fewer would have zero, one, or two quarters with earnings.

TABLE 7

Interpretation of Ordered Probit Results: Number of Quarters with Earnings ${ }^{a}$

\begin{tabular}{lccc}
\hline & \multicolumn{3}{c}{ Marginal Effect on the Probability of Quarters with Earnings } \\
\cline { 2 - 4 } Variable & Zero Quarters & Four Quarters & Eight Quarters \\
\hline Less than high school degree & 0.0035 & 0.0099 & -0.0762 \\
High school degree & 0.0008 & 0.0028 & -0.0209 \\
Missing education info & 0.0003 & 0.0009 & -0.0070 \\
African American & 0.0010 & 0.0033 & -0.0245 \\
Hispanic & -0.0026 & -0.0125 & 0.0897 \\
Asian & -0.0022 & -0.0106 & 0.0758 \\
Native American & 0.0021 & 0.0061 & -0.0470 \\
Other race/ethnicity & -0.0005 & -0.0019 & 0.0139 \\
Male & -0.0011 & -0.0039 & 0.0291 \\
Disabled & 0.0032 & 0.0087 & -0.0681 \\
Age & -0.0005 & -0.0018 & 0.0134 \\
Age squared & 0.00001 & 0.00002 & -0.0134 \\
Job growth & -0.0002 & -0.0009 & 0.0065 \\
RURAL*Job growth & 0.0001 & 0.0005 & -0.0035 \\
\hline
\end{tabular}

atata Statistical Software numerically calculates the marginal effects on each outcome category (StataCorp 2001a). For dummy variables, the marginal effect is calculated using a 0 to 1 change.

${ }^{14}$ Alternatively, an urban-job growth interaction term could be used in place of the rural interaction term and a test done on the statistical significance of the estimated coefficient for job growth (in rural areas). The test results are the same.

15 Stata Statistical Software numerically calculates the marginal effects on each outcome category (StataCorp 2001a). For dummy variables, the marginal effect is calculated using a 0 to 1 change. 

Rural Working Poor?

The impact of local job growth on annual earnings in the second year after intake exhibits a similar pattern. As shown in Table 8, a 1 percent increase in local employment is associated with an increase in earnings in the second year of about $\$ 252$ for those in urban areas. ${ }^{16}$ In rural areas, the impact of employment growth on earnings is somewhat smaller (about $\$ 176$ ) and is significantly different from zero at the $10 \%$ level, as seen by testing the sum of the estimated coefficients for job growth and for the rural-job growth interaction term). Similar to previous results, however, the rural-job growth interaction term by itself is not statistically significant (the p-value is 0.125 ), so the evidence that the impact differs between rural and urban areas is weak.

\section{TABLE 8}

Estimation Results: Annual Earnings ${ }^{a}$

\begin{tabular}{|c|c|c|c|}
\hline & $\begin{array}{l}\text { Estimated } \\
\text { OLS } \\
\text { Coefficient }\end{array}$ & $\begin{array}{l}\text { Estimated } \\
\text { Tobit } \\
\text { Coefficient }\end{array}$ & $\begin{array}{c}\text { Partial } \\
\text { Derivative }^{b}\end{array}$ \\
\hline Constant & $\begin{array}{c}-2411.32^{*} \\
(898.9)\end{array}$ & $\begin{array}{l}-4039.60^{* *} \\
(1055.6)\end{array}$ & - \\
\hline Less than high school degree & $\begin{array}{c}-2576.70^{* *} \\
(192.4)\end{array}$ & $\begin{array}{c}-2777.89^{* *} \\
(192.3)\end{array}$ & -2104.89 \\
\hline High school degree & $\begin{array}{c}-1105.21^{* *} \\
(146.0)\end{array}$ & $\begin{array}{c}-1447.03^{* *} \\
(151.4)\end{array}$ & -899.27 \\
\hline Missing education info & $\begin{array}{l}-469.93^{*} \\
(183.5)\end{array}$ & $\begin{array}{l}-705.02^{* *} \\
(179.1)\end{array}$ & -556.8 \\
\hline African American & $\begin{array}{c}-714.32^{* *} \\
(98.1)\end{array}$ & $\begin{array}{l}-841.71^{* *} \\
(119.9)\end{array}$ & -655.33 \\
\hline Hispanic & $\begin{array}{l}1103.78^{* *} \\
(345.1)\end{array}$ & $\begin{array}{l}1481.17^{* *} \\
(392.0)\end{array}$ & 1198.3 \\
\hline Asian & $\begin{array}{l}1162.82^{* *} \\
(285.8)\end{array}$ & $\begin{array}{l}1316.26^{* *} \\
(332.8)\end{array}$ & 1065.96 \\
\hline Native American & $\begin{array}{l}-877.25^{*} \\
(369.6)\end{array}$ & $\begin{array}{c}-1039.67^{*} \\
(415.2)\end{array}$ & -805.79 \\
\hline Other race/ethnicity & $\begin{array}{l}-117.19 \\
(276.6)\end{array}$ & $\begin{array}{r}56.48 \\
(251.6)\end{array}$ & 44.73 \\
\hline Male & $\begin{array}{l}3187.29 * * \\
(199.7)\end{array}$ & $\begin{array}{l}3364.55^{* *} \\
(228.4)\end{array}$ & 2690.32 \\
\hline Disabled & $\begin{array}{c}-1490.43^{* *} \\
(365.9)\end{array}$ & $\begin{array}{c}-1765.58^{* *} \\
(394.6)\end{array}$ & -1348.95 \\
\hline Age & $\begin{array}{l}493.75^{* *} \\
(24.5)\end{array}$ & $\begin{array}{l}526.36^{* *} \\
(31.6)\end{array}$ & 416.45 \\
\hline Age squared & $\begin{array}{l}-6.51^{* *} \\
(0.31)\end{array}$ & $\begin{array}{l}-6.98^{* *} \\
(0.42)\end{array}$ & -5.52 \\
\hline Job growth & $\begin{array}{l}272.48^{* * *} \\
(83.2)\end{array}$ & $\begin{array}{l}318.60^{* *} \\
(95.1)\end{array}$ & 252.07 \\
\hline RURAL*Job growth & $\begin{array}{l}-87.19 \\
(53.4)\end{array}$ & $\begin{array}{l}-96.24 \\
(62.7)\end{array}$ & -76.14 \\
\hline
\end{tabular}

*"Significant at the $1 \%$ level. "Significant at the $5 \%$ level. Estimated robust standard errors in parentheses.

The omitted categories are female, white, and having more than a high school education.

annual earnings is defined as the sum of quarterly earnings in the second year after intake into the Oregon Health Plan.

${ }^{b}$ The Tobit regression coefficients are scaled to obtain the partial derivatives, or slopes, and are evaluated at the sample means for continuous variables, and for $0-1$ changes for binary variables. (Means are shown in the appendix.)

${ }^{16}$ The coefficient estimates in the Tobit regression are scaled to obtain the partial derivatives, using the normal density function evaluated at the means (Greene 1997). 
TABLE 9

Estimation Results: Number of Quarters with Earnings Above Poverty

\begin{tabular}{|c|c|c|}
\hline Variable & $\begin{array}{l}\text { Estimated } \\
\text { OLS } \\
\text { Coefficient }\end{array}$ & $\begin{array}{c}\text { Estimated } \\
\text { Ordered Probit } \\
\text { Coefficient }\end{array}$ \\
\hline Constant & $\begin{array}{l}-2.1605^{* *} \\
(0.3365)\end{array}$ & - \\
\hline Less than high school degree & $\begin{array}{l}-0.9108^{* *} \\
(0.0765)\end{array}$ & $\begin{array}{l}-0.4117^{* *} \\
(0.0204)\end{array}$ \\
\hline High school degree & $\begin{array}{l}-0.4420^{* *} \\
(0.0589)\end{array}$ & $\begin{array}{l}-0.1894^{* *} \\
(0.0236)\end{array}$ \\
\hline Missing education info & $\begin{array}{l}-0.2293^{* *} \\
(0.0653)\end{array}$ & $\begin{array}{l}-0.1213^{* *} \\
(0.0211)\end{array}$ \\
\hline African American & $\begin{array}{l}-0.1387^{* *} \\
(0.0309)\end{array}$ & $\begin{array}{l}-0.0535^{* *} \\
(0.0142)\end{array}$ \\
\hline Hispanic & $\begin{array}{l}0.5500^{* *} \\
(0.1339)\end{array}$ & $\begin{array}{l}0.2629 * * \\
(0.0517)\end{array}$ \\
\hline Asian & $\begin{array}{l}0.4764^{* *} \\
(0.0852)\end{array}$ & $\begin{array}{l}0.2065^{* *} \\
(0.0248)\end{array}$ \\
\hline Native American & $\begin{array}{l}-0.1650 \\
(0.1323)\end{array}$ & $\begin{array}{l}-0.0537 \\
(0.0535)\end{array}$ \\
\hline Other race/ethnicity & $\begin{array}{l}-0.2188+ \\
(0.1214)\end{array}$ & $\begin{array}{l}-0.0731 \\
(0.0446)\end{array}$ \\
\hline Male & $\begin{array}{l}1.3127^{* *} \\
(0.1060)\end{array}$ & $\begin{array}{l}0.5755^{* *} \\
(0.0649)\end{array}$ \\
\hline Disabled & $\begin{array}{l}-0.5837^{* *} \\
(0.0724)\end{array}$ & $\begin{array}{l}-0.2665^{* *} \\
(0.0192)\end{array}$ \\
\hline Age & $\begin{array}{l}0.1959^{* *} \\
(0.0056)\end{array}$ & $\begin{array}{l}0.0905^{* *} \\
(0.0037)\end{array}$ \\
\hline Age squared & $\begin{array}{l}-0.0026^{* *} \\
(0.0001)\end{array}$ & $\begin{array}{l}-0.00121^{* *} \\
(0.00005)\end{array}$ \\
\hline Job growth & $\begin{array}{l}0.1111^{* *} \\
(0.0376)\end{array}$ & $\begin{array}{l}0.0515^{* *} \\
(0.0173)\end{array}$ \\
\hline RURAL*Job growth & $\begin{array}{l}-0.0360+ \\
(0.0207)\end{array}$ & $\begin{array}{l}-0.01608+ \\
(0.0097)\end{array}$ \\
\hline
\end{tabular}

*4 Significant at the $1 \%$ level. "Significant at the $5 \%$ level. +Significant at the $10 \%$ level. Estimated robust standard errors in parentheses.

The omitted categories are female, white, and having more than a high school education.

The third outcome measure, quarters with earnings above the poverty threshold, is analyzed using an ordered probit model. OHP participants in rural areas experience slightly fewer quarters with earnings above the poverty threshold than those in urban areas. Again, better economic conditions are associated with better outcomes (more quarters with above-poverty earnings) (see Table 9). Higher employment growth is associated with a higher probability of more quarters with earnings above poverty. In this case, the rural-employment growth interaction term is statistically significant at the $10 \%$ level, suggesting a smaller positive impact due to job growth in rural areas. Further, the rural impact of job growth (tested by summing the coefficients on job growth and on the rural-job growth interaction term) is not significantly different from zero. Table 10 provides the estimated marginal effects of each variable on the probability of zero, four, or eight quarters with earnings above poverty. Higher job growth is associated with a higher probability of more quarters of earnings above poverty. The impact of job 

Rural Working Poor?

growth appears to be stronger in urban areas than in rural areas, though again the evidence is suggestive rather than conclusive.

TABLE 10

Interpretation of Ordered Probit Results: Number of Quarters with Earnings Above Poverty ${ }^{a}$

\begin{tabular}{lccc}
\hline \multirow{2}{*}{ Variable } & \multicolumn{3}{c}{ Marginal Effect on the Probability of Quarters with Earnings } \\
\cline { 2 - 4 } & Zero Qtrs. & Four Qtrs. & Eight Qtrs. \\
\hline Less than high school degree & 0.1624 & -0.0182 & -0.0394 \\
High school degree & 0.0754 & -0.0081 & -0.0215 \\
Missing education info & 0.0483 & -0.0051 & -0.0144 \\
African American & 0.0213 & -0.0023 & -0.0062 \\
Hispanic & -0.1032 & 0.0101 & 0.0372 \\
Asian & -0.0812 & 0.0081 & 0.0288 \\
Native American & 0.0214 & -0.0023 & -0.0062 \\
Other race/ethnicity & 0.0291 & -0.0031 & -0.0083 \\
Male & -0.2251 & 0.0226 & 0.0764 \\
Disabled & 0.1058 & -0.0118 & -0.0263 \\
Age & -0.0360 & 0.0038 & 0.0109 \\
Age squared & 0.00048 & -0.00005 & -0.0002 \\
Job growth & -0.0205 & 0.0022 & 0.0062 \\
RURAL*Job growth & 0.0064 & -0.0007 & -0.0019 \\
\hline
\end{tabular}

${ }^{\mathrm{a}}$ Stata ${ }^{\circledR}$ Statistical Software numerically calculates the marginal effects on each outcome category (StataCorp 2001a). For dummy variables, the marginal effect is calculated using a 0 to 1 change.

Labor market processes may differ between men and women, so typically estimation of labor market equations is done separately by gender. This study is focused on the impact of local labor market conditions on outcomes rather than gender differences. Nonetheless, the models are estimated separately for men and women to examine whether the impact of job growth differs by gender. The results, summarized in Tables 11 and 12 for all three outcome measures, show the same basic pattern for men and women. ${ }^{17}$ Job growth is associated with more quarters worked for both men and women in urban areas. The estimated rural-job growth interaction term in the quarters worked model is negative for both men and women, though not significant at the 5 percent level. The results by gender for quarters with above poverty earnings also show job growth increasing the probability of more quarters for both men and women in urban areas. The ruraljob growth interaction term is negative for both men and women in the quarters with above-poverty earnings model, and is significant at the $5 \%$ level for women.

Earnings in the second year after intake also improve for both men and women in areas with higher job growth. A 1 percent increase in job growth is associated with an increase of $\$ 292$ for men and $\$ 226$ for women in urban areas (Table 12). The rural-job growth interaction term is negative and significant at the $10 \%$ level for women and not significant for men.

${ }^{17}$ Note that most of the male-female differences are statistically significant at the $5 \%$ level. 
TABLE 11

Comparison of Separate Estimations for Men and Women

\begin{tabular}{|c|c|c|c|c|}
\hline & \multirow{2}{*}{$\begin{array}{c}\text { Ordered } \\
\text { Probit Coeff. }\end{array}$} & \multicolumn{3}{|c|}{ Marginal Effect on Number of Ouarters ${ }^{\mathrm{a}}$} \\
\hline & & Zero & Four & Eight \\
\hline \multicolumn{5}{|c|}{ Dependent variable: Quarters with earnings } \\
\hline \multicolumn{5}{|c|}{ Men only } \\
\hline Job growth & $\begin{array}{l}0.0201^{* *} \\
(0.0054)\end{array}$ & -0.0002 & -0.0011 & 0.0079 \\
\hline RURAL*job growth & $\begin{array}{l}-0.0127 \\
(0.0098)\end{array}$ & 0.0001 & 0.0007 & -0.0050 \\
\hline \multicolumn{5}{|l|}{ Women only } \\
\hline Job growth & $\begin{array}{l}0.0151^{* *} \\
(0.0077)\end{array}$ & -0.0003 & -0.0008 & 0.0058 \\
\hline RURAL*job growth & $\begin{array}{l}-0.0068 \\
(0.0074)\end{array}$ & 0.0001 & 0.0004 & -0.0026 \\
\hline \multicolumn{5}{|c|}{ Dependent variable: Quarters with earnings above poverty } \\
\hline \multicolumn{5}{|c|}{ Men only } \\
\hline Job growth & $\begin{array}{l}0.0347^{* *} \\
(0.0112)\end{array}$ & -0.0126 & 0.0010 & 0.0066 \\
\hline RURAL*job growth & $\begin{array}{l}-0.0073 \\
(0.0109)\end{array}$ & 0.0027 & -0.0002 & -0.0014 \\
\hline \multicolumn{5}{|l|}{ Women only } \\
\hline Job growth & $\begin{array}{l}0.0655^{* *} \\
(0.0241)\end{array}$ & -0.0257 & 0.0028 & 0.0055 \\
\hline RURAL*job growth & $\begin{array}{l}-0.0236^{*} \\
(0.0111)\end{array}$ & 0.0092 & -0.0010 & -0.0020 \\
\hline
\end{tabular}

**Significant at the $1 \%$ level. "Significant at the 5\% level. +Significant at the $10 \%$ level. Estimated robust standard errors in parentheses. Control variables in all equations include education, race/ethnicity, age and age squared, and disability status.

${ }^{2}$ Stata ${ }^{\circledR}$ Statistical Software numerically calculates the marginal effects on each outcome category (StataCorp 2001a). For dummy variables, the marginal effect is calculated using a 0 to 1 change.

\section{TABLE 12}

Comparison of Separate Estimations for Men and Women Dependent Variable: Annual Earnings in Second Year after Intake

\begin{tabular}{|c|c|c|c|}
\hline & $\begin{array}{l}\text { Estimated OLS } \\
\text { Coefficient }\end{array}$ & $\begin{array}{l}\text { Estimated Tobit } \\
\text { Coefficient }\end{array}$ & $\begin{array}{c}\text { Partial } \\
\text { Derivative }^{\mathrm{a}}\end{array}$ \\
\hline \multicolumn{4}{|l|}{ Men only } \\
\hline Job growth & $\begin{array}{l}309.53^{* *} \\
(76.7)\end{array}$ & $\begin{array}{l}362.29 * * \\
(86.33)\end{array}$ & 292.20 \\
\hline RURAL*job growth & $\begin{array}{l}-66.33 \\
(77.8)\end{array}$ & $\begin{array}{l}-82.19 \\
(91.07)\end{array}$ & -66.29 \\
\hline Estimated rural job growth impact ${ }^{b}$ & 243.2 & & 225.91 \\
\hline \multicolumn{4}{|l|}{ Women only } \\
\hline Job growth & $\begin{array}{l}247.44^{*} \\
(94.9)\end{array}$ & $\begin{array}{l}287.94^{* *} \\
(109.0)\end{array}$ & 226.00 \\
\hline RURAL*job growth & $\begin{array}{c}-102.01+ \\
(49.8)\end{array}$ & $\begin{array}{c}-108.29+ \\
(59.0)\end{array}$ & -85.00 \\
\hline Estimated rural job growth impact & 145.43 & & 141.00 \\
\hline
\end{tabular}

**Significant at the 1\% level. "Significant at the $5 \%$ level. +Significant at the $10 \%$ level. Estimated robust standard errors in parentheses. Control variables in all equations include education, race/ethnicity, age and age squared, and disability status.

${ }^{a}$ The Tobit coefficients are scaled to obtain the partial derivatives, or slopes, and are evaluated at the sample means for continuous variables and for 0-1 changes for binary variables.

"The "rural job growth impact" is calculated by summing the coefficients on job growth and on the interaction term between job growth and the rural dummy variable. 
The results for all three outcome measures reflect a robust pattern: job growth improves the economic outcomes for these working poor adults in urban areas. This result confirms previous studies such as Freeman and Rodgers (1999), who use metropolitan statistical area data and find that the economic expansion in the 1990s generally helped improve the labor market outcomes of economically disadvantaged groups. The impact of job growth in rural areas, the key focus of this study, is less clear. Based solely on standard tests of statistical significance, one could conclude that the impact of job growth does not differ in rural and urban areas. However, the consistency of the estimated coefficients (and occasional significance) suggests that there is weak evidence that the impact of job growth is not as strong in rural areas as in urban areas. With only 18 commuting zones in Oregon, there may not be enough variation across the rural and urban areas to estimate the rural differential precisely. In addition, the hypothesis that the impact of job growth in rural areas is zero cannot be rejected. Studies using data from more states and more rural areas are needed to determine whether the rural impact differs, or to conclude definitively that it does not.

\section{CONCLUSION}

The prospects for stable employment and steady earnings growth for the working poor are, for the most part, fairly bleak. Working poor adults in Oregon increased their employment time and earnings over the eight quarters, but these gains were relatively modest for most. For nearly half of these adults, quarterly earnings were below a typical poverty threshold in every quarter. On the other hand, close to 60 percent experienced at least one quarter with earnings above poverty, suggesting the potential for earnings at a level to support a family. The problem, in part, is the frequency of job changes and periods of nonemployment. About 40 percent worked all eight quarters after intake. But for the nearly 60 percent whose employment is intermittent, total earnings are clearly constrained by periods of unemployment.

Average earnings and employment frequency varied considerably across Oregon's commuting zones, with outcomes generally somewhat worse in the rural areas. The urban-rural gap in average quarterly earnings increased from 5 to 15 percent during the two years after intake for these working poor adults. Fewer adults worked in all eight quarters in the rural areas, and they experienced more quarters with low earnings relative to their urban counterparts.

Better economic conditions help the working poor, resulting in slightly higher earnings, more frequent employment, and more quarters with earnings above the poverty level in urban areas. However, these effects are fairly small and, in addition, may not be as strong for those living in rural areas. The negative sign of the estimated rural interaction term in all models suggests that the impact of job growth is not as strong in rural areas as in urban areas. In addition, the finding that the estimated effect of job growth in rural areas is not statistically significant from zero in most of the models provides additional evidence that the effect is 
weaker in rural areas. Additional research to measure the impact in rural areas more precisely is needed. If true, the smaller rural job growth impact would raise concerns about the ability of low-income workers or former welfare recipients to achieve economic self-sufficiency in rural areas.

The finding that the rural interaction term is significant and negative for women in the earnings and quarters with above-poverty earnings models suggests that job growth in rural areas is not as effective in lifting working poor women out of poverty as it is in urban areas. It may be that rural labor markets, for whatever reason, function less well. For example, the impact of overall employment growth may be weaker because of differences in industrial structure between rural and urban areas. More importantly, perhaps, barriers to an individual's economic "success" may be greater in rural areas, for example, where child care and transportation access may be more limited. As a result, policies to boost overall job growth may not help the rural working poor as much as the working poor in urban areas.

\section{APPENDIX}

Means of Sample Data

Variable

Less than high school degree

High school degree

Missing education info

African American

Hispanic

Asian

Native American

Other race/ethnicity

Male

Disabled

Age

Age squared

Earnings in intake quarter

Job growth

RURAL*Job growth

Number of quarters worked

Number of quarters with earnings $>\$ 3,160$

Average earnings in second year after intake

Sample size $=60,160$.
Sample Mean

0.1371

0.3046

0.4385

0.0286

0.0952

0.0250

0.0143

0.0209

0.4055

0.0275

32.17

$1,128.24$

$1,784.33$

6.87

1.153

5.893

2.119

$\$ 8,348$

\section{REFERENCES}

Bartik, T.J. Who Benefits From State and Local Economic Development Policies? Kalamazoo, Mich.: W.E. Upjohn Institute, 1991.

"The Distributional Effects of Local Labor Demand and Industrial Mix: Estimates Using Individual Panel Data." Journal of Urban Economics 40 (1996), 150-178.

Bartik, T.J., and R.W. Eberts. "Examining the Effect of Industry Trends and Structure on Welfare Caseloads." W.E. Upjohn Institute for Employment Research working paper. Kalamazoo, Mich., February 1999. 
How Much Does Local Job Growth Improve Employment Outcomes of the 273 Rural Working Poor?

Blank, R.M. “What Causes Public Assistance Caseloads to Grow?" NBER Working Paper No. 5149. Cambridge, Mass., December 1997.

Bound, J., and H.J. Holzer. "Demand Shifts, Population Adjustments, and Labor Market Outcomes During the 1980s." NBER Working Paper No. 5685. Cambridge, Mass., 1996.

Brown, D.L., and T.A. Hirschl. "Household Poverty in Rural and MetropolitanCore Areas of the United States." Rural Sociology 60 (1) (1995), 44-66.

Cain, G., and R. Finnie. "The Black-White Difference in Youth Employment: Evidence for Demand-Side Factors." Journal of Labor Economics 8 (1, part 2) (1990), S364-S395.

Cameron, A.C., and P.K. Trivedi. Regression Analysis of Count Data. Cambridge, UK: Cambridge University Press, 1998.

Deavers, K.L., and R.A. Hoppe. "Overview of the Rural Poor in the 1980s" in C.M. Duncan (ed.) Rural Poverty in America. Westport, Conn.: Auburn House, 1992.

Duncan, C.M. “Understanding Persistent Poverty: Social Class Context in Rural Communities." Rural Sociology 61 (1) (1996), 103-124.

Findeis, J., and L. Jensen. "Employment Opportunities in Rural Areas: Implications for Poverty in a Changing Policy Environment." American Journal of Agricultural Economics 80 (5) (1998), 1000-1007.

Findeis, J., S.M. Smith, D. McLaughlin, and A. Jordan. "Poverty and Work: Utilization of Labor Resources Among the Rural Poor." Final Report to the Ford Foundation Rural Poverty Program and the Rural Economic Policy Program of the Aspen Institute, November 1992.

Fitzgerald, J.M. "Local Labor Markets and Local Area Effects on Welfare Duration." Journal of Policy Analysis and Management 14 (1) (1995), 43-67.

Freeman, R.B., and W. Rodgers III. "Area Economic Conditions and The Labor Market Outcomes of Young Men in the 1990s Expansion." NBER Working Paper 7073. Cambridge, Mass., April 1999.

Gorham, L. "The Growing Problem of Low Earnings in Rural Areas." In C.M. Duncan (ed.) Rural Poverty in America. Westport, Conn.: Auburn House, 1992.

Greene, W.H. Econometric Analysis. Upper Saddle River, N.J.: Prentice Hall, 1997.

Harris, K.M. "Life After Welfare: Women, Work, and Repeat Dependency." American Sociological Review 61 (3) (1996), 407-426.

Hoynes, H.W. "Local Labor Markets and Welfare Spells: Do Demand Conditions Matter?" The Review of Economics and Statistics 82 (3) (2000), 351-368.

Lichter, D., and L. Jensen. "Rural America in Transition: Poverty and Welfare at the Turn of the 21st Century". In B.Weber, G. Duncan, and L. Whitener (eds.) Rural Dimensions of Welfare Reform. Kalamazoo, Mich.: W.E. Upjohn Institute, 2002.

Mills, B. "Are Spells of Unemployment Longer in Non-Metropolitan Areas: NonParametric and Semi-Parametric Evidence." Journal of Regional Science 40 (4) (2000), 697-718. 
Parrott, S. "Welfare Recipients Who Find Jobs: What Do We Know about Their Employment and Earnings?" Washington, D.C.: Center on Budget and Policy Priorities, November 1998.

Pavetti, L. "Against the Odds: Steady Employment Among Low-Skilled Workers." Washington, D.C.: Urban Institute, July 1997.

Pavetti, L., and G. Acs. "Moving Up, Moving Out, or Going Nowhere? A Study of the Employment Patterns of Young Women." Washington, D.C.: Urban Institute, July 1995.

Rangarajan, A. "Taking the First Steps: Helping Welfare Recipients Who Get Jobs Keep Them." Princeton, N.J.: Mathematica Policy Research, November 1996.

StataCorp. Stata Statistical Software: Release 7.0. College Station, Tex.: Stata Corporation, 2001a.

StataCorp. Stata User's Guide: Release 7.0. College Station, Tex.: Stata Corporation, $2001 \mathrm{~b}$.

Tickamyer, A.R. "The Working Poor in Rural Labor Markets: The Example of the Southeastern United States." In C.M. Duncan (ed.) Rural Poverty in America. Westport, Conn.: Auburn House, 1992.

Tolbert, C.M., and M. Sizer. "U.S. Commuting Zones and Labor Market Areas: A 1990 Update." U.S. Department of Agriculture Economic Research Service Staff Paper No. 9614. Washington, D.C., September 1996.

U.S. Council of Economic Advisors. "Explaining the Decline in Welfare Receipt, 1993-1996." Technical Report. Washington, D.C., 1997.

Ziliak, J.P., D.N. Figlio, E.E. Davis, and L.S. Connolly. "Accounting for the Decline in AFDC Caseloads: Welfare Reform or the Economy?" Journal of Human Resources 35 (3) (2000), 570-586. 